\title{
Inhibitory Effects of Prunin on Photo-aging in Human Keratinocytes (HaCaT) Damaged by UVB Radiation
}

\author{
Ji Young Ryu ${ }^{1}$, Sung Ja Rhie ${ }^{1}$, Kye Hwa Lim² ${ }^{2}$, Young Eun $\mathrm{Choi}^{3}$, Hyo Sun $\mathrm{Han}^{4}$, Hyun Ok Yang ${ }^{5}$, Eun Ju Na ${ }^{5 *}$ \\ ${ }^{1}$ Department of Beauty Care Design, Halla University, Wonju-si, Gangwon-do, Korea \\ ${ }^{2}$ Department of Beauty Care, Sangji Youngseo College, Wonju-si, Gangwon-do, Korea \\ ${ }^{3}$ Department of Beauty Management, Myongji College, Seoul, Korea \\ ${ }^{4}$ Korea Institute of Dermatological Sciences, Seoul, Korea \\ ${ }^{5}$ Department of Beauty \& Cosmetics, Wonkang College, Iksan-si, Jeolla-do, Korea
}

"Corresponding author: Ju Eun $\mathrm{Na}$,

Department of Beauty \& Cosmetics,

Wonkang College, Iksan-daro 460, Iksan-si,

Jeollabuk-do, Korea

Tel.: +82 264351009

Email: ejhk1010@naver.com

Received January 16, 2019

Revised February 11, 2019

Accepted February 14, 2019

Published March 30, 2019

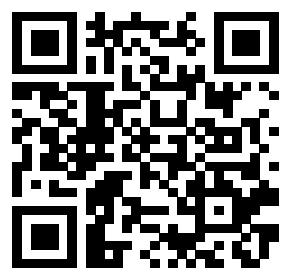

\begin{abstract}
Purpose: The aim of this study was to investigate the effects of prunin on photoaging in human keratinocytes (HaCaT) damaged by UVB radiation, so as to find out whether prunin can be used as an effective anti-aging ingredient in cosmetic products. Methods: Quantitative real-time polymerase chain reaction (qRT-PCR) was used to identify the increased expression of MMP1 MRNA and decreased expression of COL1A1 mRNA due to UVB, and luciferase reporter assay was used to determine whether the change in MMP1 mRNA is related to AP-1 transcriptional activity. Furthermore, ELISA analysis was used to determine the change in type I procollagen production. Results: Prunin protected cells from UVB-induced cytotoxicity, and the increased expression of MMP1 mRNA due to oxidative stress in UVB-damaged $\mathrm{HaCaT}$ decreased in a concentration-dependent manner. AP-1 transcriptional activity also decreased in a concentration-dependent manner. The expression of Type I procollagen and COL1A1 mRNA increased in a concentration-dependent manner. Conclusion: This study found that prunin has an inhibitory efficacy on photoaging due to UV radiation, which is a leading cause of oxidative stress. Thus prunin can be used as an effective cosmetic raw material for inhibiting photoaging. However, it will be necessary to conduct experiments on the human body to find a practical way of applying prunin as a cosmetic raw material for the skin.
\end{abstract}

Keywords: Prunin, Photo-aging, Human keratinocyte, MMP1, Ultraviolet B

\section{Introduction}

나이가 들어감에 따라 피부에서 노화가 진행되면 기능적인 특 징과 정상적인 구조가 감소한다. 이는 생물학적으로 명확히 구별 되는 것으로 내인성 노화와 외인성 노화에 의해 일어난다. 내인 성 노화는 나이가 들어감에 따라 자연스럽게 발생하는 노화로 이 는 자연노화 과정에 의해 나타나며 다른 장기에서 나타나는 노화 와 비슷한 형태로 피부에 영향을 준다. 외인성 노화는 다양한 환 경적인 요소 중 특히 UVB가 노화를 일으키는 주요원인으로 외 부적인 요소에 의해 발생하는 광노화에 의한 노화를 말한다(ElDomyati et al., 2002). UVA와 UVB는 일시적, 영구적인 유 전자의 손상과 분화, 성장, 노화 및 결체조직 퇴행과 관계된 세
포질내에서 신호 전달 경로를 활성화시킨다(Wlaschek et al., 2001). 자외선이 피부의 세포 내 신호 전달체계에 영향을 주어 $\mathrm{DNA}$ 손상, 유전자 발현을 손상시켜 세포의 노화와 세포의 사멸 을 일으킨다(Lee et al., 2012).

피부는 표피, 진피, 피하조직으로 구분되며, 그 중 진피에서 세포외기질(extra cellular matrix)의 구성 성분인 콜라겐은 강 도와 장력을 피부에 주는 것으로 진피의 약 $90 \%$ 정도를 차지한 다. 콜라겐의 중요한 구성 성분으로 collagen type-I (제1형 콜 라겐, COL1A1)이 대부분을 차지하고 있으며 조직의 기능, 구 조를 유지하는데 중요한 단백질의 역할을 한다(Mays et al., 1988). 단백질 분해 효소인 matrix metalloproteinase (MMP), 세린 단백질 분해 효소, 시스틴 단백질 분해 효소는 세포외기질 
을 파괴한다(Charous et al., 1997). 이 중 노화의 중요한 역할 을 하는 것으로 collagenase group에서는 MMP-1, MMP-8, $\mathrm{MMP}-13$ 이 포함되어 있고, 제 I형, II형, III형 콜라겐을 분해한 다(Kusukawa et al., 1996). MMP 계열에서 발현증가는 자외선 과 같은 산화적 스트레스로 유도되며, 자외선은 $\mathrm{MMP}-1$ 의 합성 을 증가시켜서 피부의 콜라겐을 분해하여 type I procollagen 의 합성을 감소시킨다(Rittié \& Fisher, 2002). 노화가 진행될 때 활성 산소는 activator protein 1 (AP-1)을 구성하는 단백 질의 발현의 증가와 일치하는 연구결과가 보고되었다(Fisher et al., 1996). 자외선과 같은 피부를 자극하는 산화적인 스트레스 에 의해 mitogen activated protein (MAP) kinase의 경로를 활 성화해 $\mathrm{AP}-1$ 발현을 유도하고 $\mathrm{MMP}$ 의 발현을 증가시켜서 세포 외기질을 분해하여 결국 피부에 주름생성을 촉진시킨다(Choi et al., 1991).

Prunin은 플라보노이드(flavonoid)의 플라바논(flavanones) 배당체로서 왕벚나무 Prunus yedoensis Matsumura (장미 과) 등의 벚꽃재에 많이 함유되어 있다. Prunus davidiana Fr. (장미과)의 줄기는 한국의 민간요법에서 신경염, 류머티스 등 의 치료에 사용되며 Prunin davidiana의 줄기에는 플라 보닌 (naringenin 7-O-glucoside)이 항산화, 항염증 및 심장 보호 효과 등 여러 종류의 플라보노이드를 함유하고 있다(Roshchin \& Gerashchenko, 1973; Jung et al., 2003). Prunin에 대해서는 항산화, 항균 효과, 혈당저하 및 혈행 개선에 대한 효과가 보고되 었다(Han et al., 2008; Han et al., 2012). 또한 prunin에 관 한 연구는 약학, 화학, 의학 등에서의 항염(Céliz et al., 2010; Céliz et al., 2011), 항산화(Céliz et al., 2013), 혈행 개선(Itoh et al., 2010), 당뇨와 관련된 혈당 및 인슐린 저하(Choi et al., 1991) 등에 대한 것이 대부분이고 화장품 원료로서의 가능성에 관한 연구는 매우 미흡합니다. 따라서 본 연구에서는 prunin이 $\mathrm{MMP}$ 발현, $\mathrm{AP}-1$ 전사활성을 조절하고 Type I procollagen 및 $C O L 1 A 1$ 의 유전자 발현의 변화를 확인하여 항노화에 관련된 기 능성 화장품 원료로서의 활용 가능성을 검증하고자 한다.

\section{Methods}

\section{1. 세포배양}

본 연구에 사용한 세포는 인간 각질형성세포주인 $\mathrm{HaCaT}$ keratinocytes cell line (ATCC, USA)을 사용하였다. HaCaT 세포주의 배양은 Dulbecco's Modified Eagle Medium (DMEM; Hyclone, USA)에 스트렙토마이신/페니실린(streptomycin 100 $\mu \mathrm{g} / \mathrm{mL}$, penicillin $100 \mathrm{IU} / \mathrm{mL}$; Invitrogen, USA) $1 \%$ 와 fetal bovine serum (FBS; Hyclone) 10\%가 함유한 배지를 사용하였 으며, 배지 환경은 $5 \% \mathrm{CO}_{2}, 37^{\circ} \mathrm{C}$ 가 유지되는 조건에서 배양하였 다.

\section{2. 시료 처리}

Prunin는 순수정제(>95\%)된 분말의 형태로 Sigma-Aldrich (USA)로부터 구매하였고 실험에 사용할 때에는 dimethyl sulfoxide (DMSO; Sigma-Aldrich)에 정적한 농도로 용해시켜 실험에 사용하였다. 세포배양 접시에 $24 \mathrm{~h}$ 동안 $\mathrm{HaCaT}$ cell (1 $\times 10^{6}$ cells/well)을 배양한 후에 적정 실험농도에 맞춰 Prunin 을 배지에 첨가하여 전 처리를 $6 \mathrm{~h}$ 동안 $\mathrm{UVB}$ 를 처리 후 $24 \mathrm{~h}$ 이 지난 후에 실험을 진행하였다. $\mathrm{HaCaT}$ 에 UVB 조사를 하기 위해 서 세포배양접시의 배지를 제거 하였다. 제거 방법은 $\mathrm{pH}$ 가 7.4 인 phosphate buffered saline (PBS)로 2회 세척하였다. 세포의 건 조를 막기 위해서 $1 \mathrm{~mL}$ 의 $\mathrm{PBS}$ 를 세척된 $\mathrm{HaCaT}$ 에 넣은 다음 세 포배양접시의 뚜껑을 연 후 UVB를 조사하였다. UVB 조사한 후 $\mathrm{PBS}$ 를 제거한 다음 다시 배지를 첨가하여 배양기에서 $24 \mathrm{~h}$ 추가 배양한 다음 실험에 사용하였다.

\section{3. 세포 생존율 측정}

세포 생존율 측정은 water-soluble tetrazolium salt-1 (WST1) assay의 원리를 이용하여 측정하였다. WST-1 assay는 세포 내에 존재하는 미토콘드리아 탈수소효소와 수용성인 tetrazolium salts가 반응해서 형성된 발색물질인 formazan을 이용해 측정 하는 실험방법이다. 96-well plate에 $3 \times 10^{3}$ cells/well의 농도 로 $\mathrm{HaCaT}$ 를 $100 \mu \mathrm{L}$ 씩 접종한 다음 $24 \mathrm{~h}$ 배양한 후 prunin을 각 각 $1,5,10,20,40 \mu \mathrm{M}$ 농도로 처리하고, $\mathrm{UVB}$ 조사한 다음 24 $\mathrm{h}$ 동안 추가 배양하였다. $1 \mathrm{~h}$ 동안 세포배양접시에 $10 \mu \mathrm{L}$ 의 $\mathrm{EZ}-$ Cytox cell viability assay kit reagent (ItsBio, Korea)를 첨가 하여 배양한 후 microplate reader (Bio-Rad, USA)를 이용하여 $490 \mathrm{~nm}$ 에서 흡광도를 측정하였다.

4. Quantitative real-time polymerase chain reaction (qRT-PCR) Prunin에 의한 $\mathrm{HaCaT}$ 에서의 유전자 발현패턴을 정량적으로

Table1. List of primers used in this study

\begin{tabular}{lcc}
\hline Gene & Forward primer & Reverse primer \\
COL1A1 & AGGGCCAAGACGAAGACATC & AGATCACGTCATCGCACAACA \\
$M M P 1$ & TCTGACGTTGATCCCAGAGAGCAG & CAGGGTGACACCAGTGACTGCAC \\
\hline
\end{tabular}

COL1A1, collagen type1 alpha1; MMP1, matrix metalloproteinase. 
A

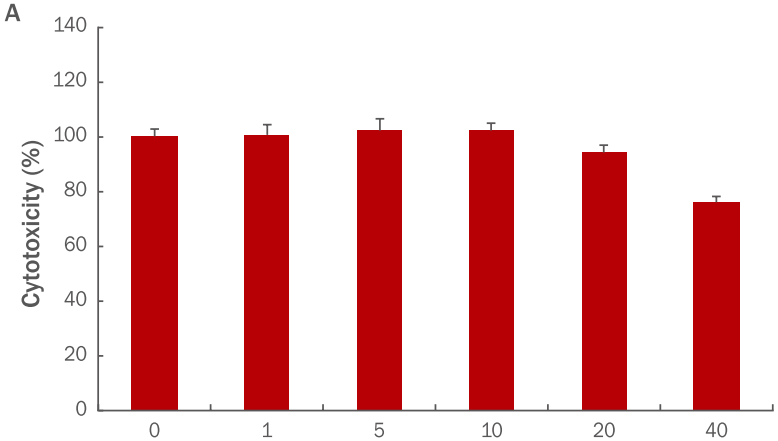

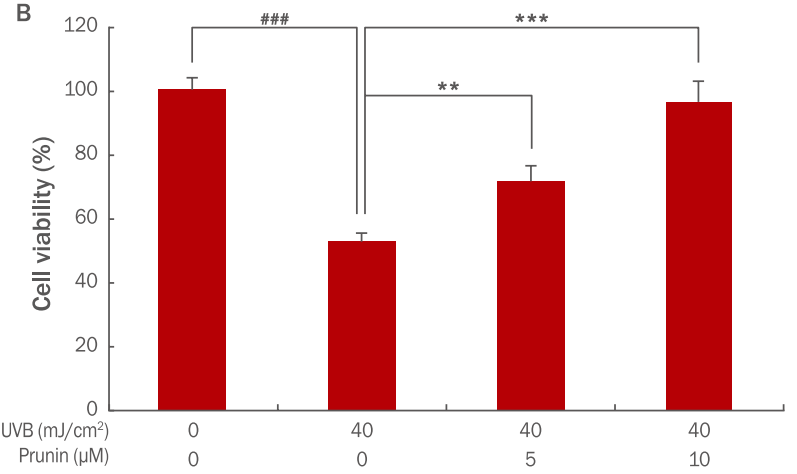

Figure 1. Cell survival analysis of UVB-irradiated and prunin treated HaCaT cells.

$\mathrm{HaCaT}$ cells were inoculated into 96-well plate at a $3 \times 10^{3}$ cells/well and incubated for $24 \mathrm{~h}$. (A) Prunin was added at various concentrations and cells were cultured for $24 \mathrm{~h}$. Survival rates were 100\%, 102\%, 102\%, 93\% and 75\% at the concentrations of prunin 1, 5, 10, 20 and $40 \mu \mathrm{M}$, respectively. (B) The cells were pretreated with prunin at 5, $10 \mu \mathrm{M}$ for $6 \mathrm{~h}$ and irradiated with $40 \mathrm{~mJ} / \mathrm{cm}^{2}$ of UVB. After $24 \mathrm{~h}$ of incubation, cell viability was determined using the WST-1 assay. Cell survival was restored in a dose-dependent manner. The results show the mean and standard deviation for three independent experiments. The graph represents the mean $\pm S D$ of the relative cell viability in each sample from triplicate experiments. The Student's $t$-test was performed to determine statistical significance $\left({ }^{* *} p<0.01\right.$; ${ }^{* * *} p<0.001$; $\#$ \#\# $p .001)$. UVB, ultraviolet B; WST-1, water-soluble tetrazolium salt.

분석하기 위해 $\mathrm{qRT}-\mathrm{PCR}$ 을 이용하였다. qRT-PCR은 PCR tube 에 $0.5 \mathrm{U}$ Ex taq DNA polymerase, $0.2 \mu \mathrm{M}$ primers, $0.8 \mathrm{mM}$ dNTP, 3mM MgCl, 20 mM Tris/HCl pH 8.4, 50 mM KCl, $1 \mathrm{X}$ SYBR green (Invitrogen)을 혼합해 반응액을 제조하였고, PCR 은 Linegene K (BioER, China)를 사용하여 진행하였다. PCR 의 유효성의 검증은 melting curve로 하였다, 각각의 유전자 발현 은 $\beta$-actin의 발현을 표준화해서 비교분석 하였다. 실험에 사용한 primer는 Table 1 과 같다.

\section{5. $\mathrm{AP}-1$ 활성 측정}

Prunin이 $\mathrm{AP}-1$ 의 활성에 영향을 주는지 확인을 위한 목적 으로 $\mathrm{AP}-1$ luciferase assay를 사용하였다. AP-1 responsive elements가 luciferase gene 앞쪽에 자리하고 있는 vector (BPS Bioscience, USA)를 구매하여 사용하였으며 transfection한 다 음 발현을 확인하였다. 96-well 세포배양접시에 농도는 $3 \times 10^{4}$ cells/well 세포를 넣고 $24 \mathrm{~h}$ 동안 배양한 다음 세포를 안정화시킨 후 $15 \mu \mathrm{L}$ 배지에 $1 \mu \mathrm{L}$ reporter gene을 섞어 준비하고 $15 \mu \mathrm{L}$ 배 지에 $0.35 \mu \mathrm{L}$ Llipofectamine 2000 를 섞어 준비하였다. 상온에 서 $25 \mathrm{~min} \mathrm{DNA}$ 희석액, Lipofectamine 2000 희석액 두가지를 섞어 반응시키고 $30 \mu \mathrm{L}$ 씩 세포배양접시에 넣고 배양기에서 $24 \mathrm{~h}$ 반응시킨다. 다음날 시약과 자극 등을 처리한 후 $24 \mathrm{~h}$ 추가 배양 한 다음 AP-1 promoter activity를 측정하였다.

\section{Procollagen type | 생산량 측정}

단백질에 특이적인 항체(antibody)를 사용하여 정량하 는 측정 방법으로 Procollagen type- I C-peptice enzme immunoassay kit (MK 101; Takara, Japan)을 사용하 여 procollagen enzyme linked immunoassay (ELISA) 를 진행하였다. Anti-PIP (procollagen type-I C-peptide) monoclonal antibody-coated plate에 각각 $100 \mu \mathrm{L}$ 씩 배양배 지를 분주하여 상온에서 $2 \mathrm{~h}$ 경과 후 5 번 $1 \mathrm{X}$ washing buffer 로 헹구어주고 peroxidase-labeled anti-PIP monoclonal antibody을 넣고 후 $3 \mathrm{~h}$ 동안 반응시킨다. $100 \mu \mathrm{L}$ 의 3,3',5,5'-tetramethylbenzidine (TMB) substrate를 넣고 상온 에서 $15 \mathrm{~min}$ 반응시킨 다음에 흡광도를 $450 \mathrm{~nm}$ 에서 측정하였 다.

\section{7. 통계분석}

모든 실험들은 동일한 조건하에 독립적으로 3 회 반복 수행하 였다. 실험결과는 평균값 \pm 표준 편차로 나타내었다. 실험 결과는 Student $t$-test로 검정하였으며, $p$-value 값이 0.05 이하인 경 우에만 통계적으로 유의하다고 하였다.

\section{Results and Discussion}

\section{Prunin의 세포 생존율 분석}

Prunin이 인간각질세포(HaCaT keratinocytes)에 미치는 세 포의 독성을 확인하기 위해 세포생존율을 WST-1 assay를 사 용하여 측정하였다. prunin을 각각 $1,5,10,20,40 \mu \mathrm{M}$ 농도 로 각각 처리하여 확인한 결과, prunin $1,5,10,20,40 \mu \mathrm{M}$ 농 도에서 $100 \%, 102 \%, 102 \%, 93 \%$ 의 생존율을 보였으나, $40 \mu \mathrm{M}$ 


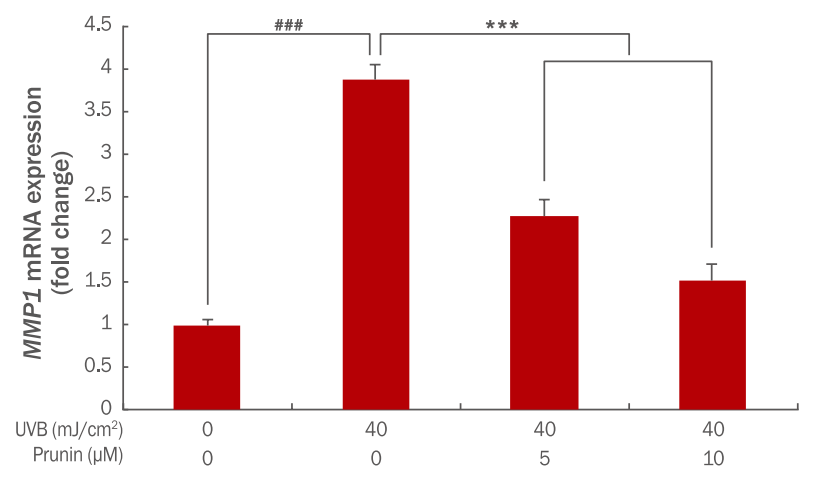

Figure 2. The effect of prunin on expression of MMP1 mRNA in UVB-irradiated HaCaT keratinocytes.

HaCaT keratinocytes $\left(2 \times 10^{5}\right.$ cells) were inoculated into $60 \mathrm{~mm}$ culture dishes and then incubated for $24 \mathrm{~h}$. Prior to UVB exposure, the cells were pre-treated at various concentrations of prunin. Then, the cells were washed with PBS and irradiated with 40 $\mathrm{mJ} / \mathrm{cm}^{2}$ UVB. After $24 \mathrm{~h}$ further incubation, the expression level of MMP1 mRNA was determined by the qRT-PCR. The graph is representative of three independent experiments (mean $\pm \mathrm{SD}$ ). The Student's $t$-test was performed to determine statistical significance $\left({ }^{* * *} p<0.001\right.$; $\left.{ }^{\# \#} p<0.001\right) . M M P 1$, matrix metalloproteinase; UVB, ultraviolet B; qRT-PCR, quantitative real-time polymerase chain reaction; $\mathrm{SD}$, standard deviation.

에서 $75 \%$ 로 세포생존율이 감소한 것으로 나타나 $40 \mu \mathrm{M}$ 이상 의 농도에서는 세포독성이 있다고 판단하였다 (Figure 1A). 또 한 UVB에 의해 손상된 $\mathrm{HaCaT}$ 에서 prunin의 세포보호 효능을 알아보기 위해 prunin을 각각 $5,10 \mu \mathrm{M}$ 의 농도로 전 처리 후 $\mathrm{UVB}$ 를 $40 \mathrm{~mJ} / \mathrm{cm}^{2}$ 를 조사한 결과 UVB만 조사된 대조군에서 세포생존율이 $53 \%$, prunin을 $5,10 \mu \mathrm{M}$ 전 처리한 경우 $71 \%$, $96 \%$ 의 세포생존율을 보여 prunin에 의해 세포생존율이 농도 의 존적으로 회복되는 것이 확인되었다(Figure $1 \mathrm{~B})$.

\section{Prunin의 $M M P 1 \mathrm{mRNA}$ 발현 변화}

산화 스트레스로 인해 $M M P 1, M M P 3$ 등의 유전자 발현이 촉 진된다. 이로 인해 피부의 주름이나 탄력저하 등이 나타나면서 피부의 노화를 유도한다(Fisher et al., 1996). Prunin이 UVB 에 의해 증가된 $M M P 1 \mathrm{mRNA}$ 가 어느 정도 회복되는지 $\mathrm{qRT}-$ $\mathrm{PCR}$ 을 통해 확인한 결과 UVB $40 \mathrm{~mJ} / \mathrm{cm}^{2}$ 에 의해서 발현량이 1 에서 3.89 으로 증가되었다. Prunin의 농도 $5,10 \mu \mathrm{M}$ 전처리 후 $40 \mathrm{~mJ} / \mathrm{cm}^{2} \mathrm{UVB}$ 조사하였을 때 발현량이 2.27, 1.52 로 감 소되었다. 즉, 농도 의존적으로 prunin이 $M M P 1 \mathrm{mRNA}$ 발현을 감소하는 것으로 확인하였다(Figure 2). 이러한 결과는 prunin 이 산화 스트레스에 의해 늘어난 $M M P 1 \mathrm{mRNA}$ 의 발현 감소가 자외선에 의한 노화에 효과가 있을 것으로 사료된다.

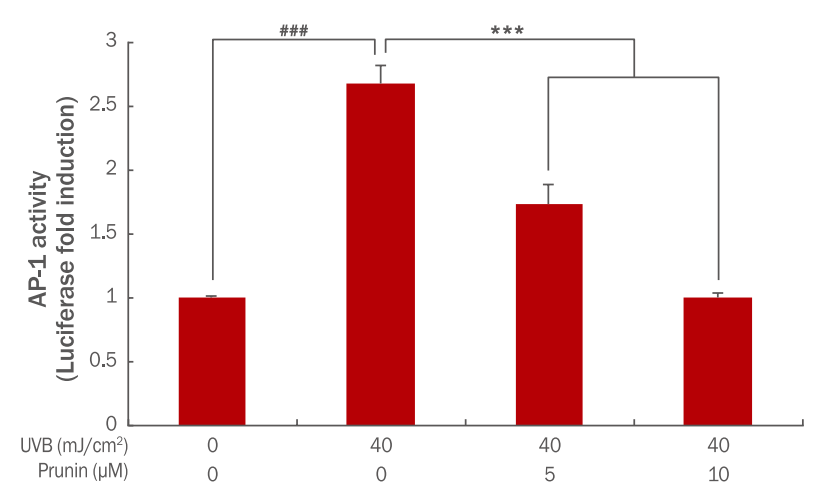

Figure 3. The effect of prunin on expression of AP-1 activity in UVB-irradiated HaCaT keratinocytes.

HaCaT keratinocytes $\left(2 \times 10^{5}\right.$ cells) were inoculated into 60 $\mathrm{mm}$ culture dishes and then incubated for $24 \mathrm{~h}$. Prior to UVB exposure, the cells were pre-treated at various concentrations of prunin. Then, the cells were washed with PBS and irradiated with $40 \mathrm{~mJ} / \mathrm{cm}^{2}$ UVB. After $24 \mathrm{~h}$ further incubation, the AP-1 activity was determined by the AP-1 luciferase assay. The graph is representative of three independent experiments (mean $\pm S D$ ). The Student's $t$-test was performed to determine statistical significance

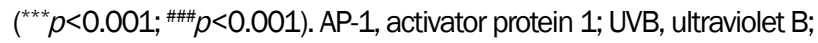
PBS, phosphate buffered saline; SD, standard deviation.

\section{Prunin의 $A P-1$ 전사활성 변화}

자외선과 같은 산화적인 스트레스로 인해 피부 자극은 MAP kinase 경로를 활성화시키므로 $\mathrm{AP}-1$ 의 발현을 유도하여 $\mathrm{MMP}$ 계열의 발현을 증가시켜 세포외기질을 분해하여 피부에 주름생 성을 촉진시킨다(Choi et al., 1991). 산화 스트레스에 의해 증 가된 활성산소가 $\mathrm{AP}-1$ 를 전사활성 시켜 $\mathrm{MMP} 1$ 의 발현을 증 가되는 것을 확인하기 위해 $\mathrm{AP}-1$ 전사활성 변화를 prunin이 $\mathrm{UVB}$ 에 의해 증가된 $\mathrm{AP}-1$ 전사활성이 어느 정도 회복되는지를 AP-1 luciferase assay를 통해서 확인한 결과 UVB $40 \mathrm{~mJ} /$ $\mathrm{cm}^{2}$ 에 의해 $\mathrm{AP}-1$ 전사활성이 1 에서 2.67으로 증가되었다. Prunin의 농도 $5,10 \mu \mathrm{M}$ 전처리 후 $40 \mathrm{~mJ} / \mathrm{cm}^{2} \mathrm{UVB}$ 조사하였 을 때 $\mathrm{AP}-1$ 전사활성이 $1.73,1.00$ 으로 감소되었다. 즉, 농도 의존적으로 prunin이 $\mathrm{AP}-1$ 전사활성을 감소시키는 것을 확인 하였다(Figure 3). 따라서 prunin이 산화 스트레스에 의해 증가 된 $\mathrm{AP}-1$ 의 활성을 감소시켜서 $\mathrm{MMP} 1$ 의 발현을 감소시키는 것 으로 확인하였다.

\section{Prunin의 Type I procollagen 변화}

Type I procollagen은 진피층의 세포외 기질에 가장 많이 차 지하고 있다(Na et al., 2018). 자외선은 MMP-1의 합성을 증 가시켜 사람의 피부에서 콜라겐을 분해하고 피부에서 type I procollagen의 합성을 감소시킨다. 피부에서 콜라겐 합성의 감 소와 상승된 $\mathrm{MMP}$ 발현은 자연적인 피부 노화로 인해 콜라겐 


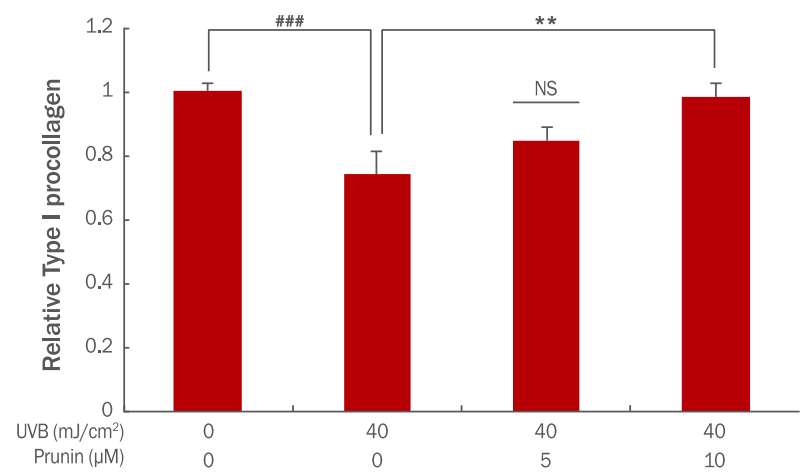

Figure 4. The effect of prunin on expression of relative type I procollagen in UVB-irradiated HaCaT keratinocytes.

HaCaT keratinocytes $\left(2 \times 10^{5}\right.$ cells) were inoculated into 60 $\mathrm{mm}$ culture dishes and then incubated for $24 \mathrm{~h}$. Prior to UVB exposure, the cells were pre-treated at various concentrations of prunin. Then, the cells were washed with PBS and irradiated with $40 \mathrm{~mJ} / \mathrm{cm}^{2}$ UVB. After further $24 \mathrm{~h}$ incubation, the relative type I procollagen was determined by the ELISA. The graph is representative of three independent experiments (mean $\pm S D$ ). The Student's $t$-test was performed to determine statistical significance $\left({ }^{* *} p<0.01 ;{ }^{\# \#} p<0.01\right)$. NS, not significant; UVB, ultraviolet B; ELISA, enzyme-linked immunosorbent assay; PBS, phosphate buffered saline; SD, standard deviation.

의 손상이 발생하고(Chung et al., 2001), 그로 인해 피부 탄력 저하 및 주름을 생성시켜 피부의 노화를 가져온다(Lee et al., 2012; Saito et al., 2004; Varani et al., 2002). MMP1 활 성으로 감소된 type I procollagen의 변화를 확인하기 위해 prunin이 UVB의 자극을 받은 type I procollagen을 어느 정 도 회복하는지 ELISA를 통해 확인한 결과, UVB $40 \mathrm{~mJ} / \mathrm{cm}^{2}$ 에 의해 type I procollagen이 1에서 0.74로 감소되었다. Prunin 의 농도 $5,10 \mu \mathrm{M}$ 전처리 후 $40 \mathrm{~mJ} / \mathrm{cm}^{2} \mathrm{UVB}$ 조사하였을 때 type I procollagen이 $0.84,0.98$ 로 증가되었다. 즉, 농도의 존적으로 prunin이 type I procollagen을 증가시키는 것으로 확인하였다(Figure 4). 따라서 prunin이 자외선에 의해 감소된 type I procollagen이 증가하여 노화를 억제하는 효과가 있을 것으로 사료된다.

\section{Prunin의 $C O L 1 A 1 \mathrm{mRNA}$ 발현 변화}

자외선을 조사하면 $\mathrm{MMP}$ 계열의 발현을 촉진시킬 뿐만 아니 라 collagen의 생성 또한 억제한다(Yoon, 2013). Collagen은 진 피의 세포의 증식, 분화, 세포의 접착력, 탄력과 치밀도 및 조직 의 결합력 등에도 관여한다(Perlish et al., 1998). Collagen은 다양한 타입으로 존재하며 type I collagen은 피부와 뼈에 존재 하는 대표적인 collagen으로 collagen type1 alpha1 (COL1A1) 과 collagen type1 alpha2 (COL1A2)의 유전자에 의해서 합성 된다(Yoon, 2013). Prunin이 피부의 노화를 어느 정도 감소시

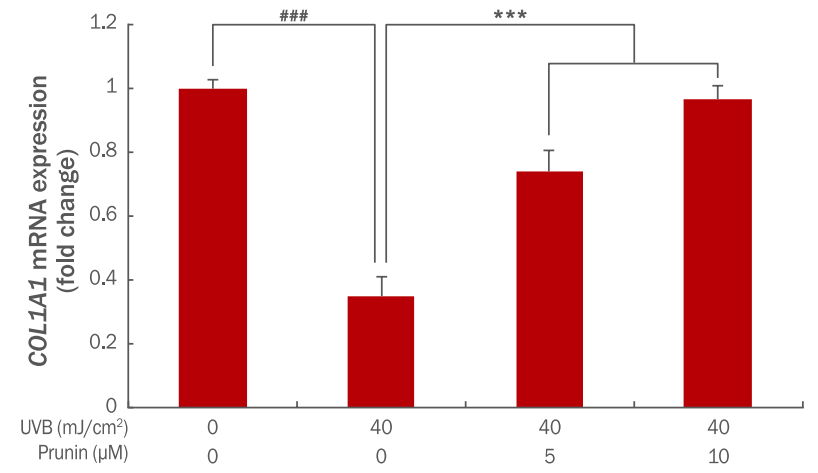

Figure 5. The effect of prunin on expression of COL1A1mRNA in UVB-irradiated HaCaT keratinocytes.

HaCaT keratinocytes $\left(2 \times 10^{5}\right.$ cells $)$ were inoculated into $60 \mathrm{~mm}$ culture dishes and then incubated for $24 \mathrm{~h}$. Prior to UVB exposure, the cells were pre-treated at various concentrations of prunin. Then, the cells were washed with PBS and irradiated with 40 $\mathrm{mJ} / \mathrm{cm}^{2}$ UVB. After $24 \mathrm{~h}$ further incubation, the expression level of COL1A1 mRNA was determined by qRT-PCR. The graph is representative of three independent experiments (mean $\pm S D$ ). The Student's $t$-test was performed to determine statistical significance $\left({ }^{* * *} p<0.001 ;{ }^{\# \#} p<0.001\right)$. COL1A1, collagen type1 alpha1; UVB, ultraviolet B; qRT-PCR, quantitative real-time polymerase chain reaction; PBS, phosphate buffered saline; SD, standard deviation.

키는지 그 효과를 알아보기 위해 type I collagen을 생성하는 COL1A1 mRNA 발현량을 확인하였다. Prunin이 UVB에 의해 증가된 $C O L 1 A 1 \mathrm{mRNA}$ 가 어느 정도 회복되는지를 $\mathrm{qRT}-\mathrm{PCR}$ 을 사용하여 확인한 결과, UVB $40 \mathrm{~mJ} / \mathrm{cm}^{2}$ 에 의해 $C O L 1 A 1$ $\mathrm{mRNA}$ 발현량이 1 에서 0.34 로 감소되었다. Prunin의 농도를 $5,10 \mu \mathrm{M}$ 전처리 후 $40 \mathrm{~mJ} / \mathrm{cm}^{2} \mathrm{UVB}$ 조사하였을 때 $C O L 1 A 1$ mRNA 발현량이 $0.74,0.96$ 으로 증가되었다. 즉, 농도 의존적 으로 prunin이 발현량을 증가시키는 것으로 확인하였다(Figure 5). 따라서 prunin이 자외선에 의해 감소된 $C O L 1 A 1 \mathrm{mRNA}$ 의 발현을 증가함으로 광노화에 효능이 있는 것으로 사료된다.

\section{Conclusion}

본 연구에서는 $\mathrm{HaCaT}$ 에서 prunin을 농도별로 전 처리하고 $\mathrm{UVB}$ 를 조사하여 세포손상을 유도한 후 증가된 $M M P 1 \mathrm{mRNA}$ 발현, AP-1 전사활성을 확인하고 자외선에 의해 감소된 Type I procollagen, COL $1 A 1$ 의 유전자의 발현 변화를 확인하여 광노 화에 효과가 있는지를 확인하였다. 그 결과 prunin이 UVB에 의 해 손상된 $\mathrm{HaCaT}$ 의 세포 손상을 보호하는 효과를 확인하였다. Prunin이 MMP1 mRNA 발현과 $\mathrm{AP}-1$ 전사활성을 감소하였고 Type I procollagen, COL1A1 mRNA 발현을 증가시켜 산화 스 트레스에 의해 노화를 억제할 수 있는 것 확인되었다. 그러므로 
prunin은 $\mathrm{HaCaT}$ 에서 광노화에 효과를 가진 화장품 원료로서의 활용 가능성이 있음을 확인하였다.

\section{References}

Céliz G, Daz M, Audisio MC. Antibacterial activity of naringin derivatives against pathogenic strains. Journal of Applied Microbiology, 111: 731-738, 2011.

Céliz G, Audisio MC, Daz M. Antimicrobial properties of prunin, a citric flavanone glucoside, and its prunin 6"---lauroyl ester. Journal of Applied Microbiology, 109: 1450-1457, 2010.

Céliz G, Alfaro FF, Cappellini C, Daz M, Verstraeten SV. Prunin- and hesperetin glucoside-alkyl (C4-C18) esters interaction with Jurkat cells plasma membrane: consequences on membrane physical properties and antioxidant capacity. Food and Chemical Toxicology, 55: 411-423, 2013.

Charous SJ, Stricklin GP, Nanney LB, Netterville JL, Burkey B. Expression of matrix metalloproteinases and tissue inhibitor of metalloproteinases in head and neck squamous cell carcinoma. The Annals of Otology, Rhinology \& Laryngology, 106: 271-278, 1997.

Choi JS, Yokozawa T, Oura H. Improvement of hyperglycemia and hyperlipemia in streptozotocin-diabetic rats by a methanolic extract of Prunus davidiana stems and its main component, pruning. Planta Medica, 57: 208-211, 1991.

Chung JH, Seo JY, Choi HR, Lee MK, Youn CS, Rhie G, Cho KH, Kim KH, Park KC, Eun HC. Modulation of skin collagen metabolism in aged and photoaged human skin in vivo. The Journal of Investigative Dermatology, 117: 12181224, 2001.

El-Domyati M, Attia S, Saleh F, Brown D, Birk DE, Gasparro $\mathrm{F}$, Ahmad $\mathrm{H}$, Uitto J. Intrinsic aging vs. photoaging: comparative histopathological, immunohistochemical and ultrastructural study of skin. Experimental Dermatology, 11: 398-405, 2002.

Fisher GJ, Datta SC, Talwar HS, Wang ZQ, Varani J, Kang S, Voorhees JJ. Molecular basis of sun-induced premature skin ageing retinoid antagonism. Nature, 379: 335-339, 1996.
Han XZ, Gao S, Cheng YN, Sun YZ, Liu W, Tang LL, Ren DM. Protective effect of naringenin-7-0-glucoside against oxidative stress induced by doxorubicin in $\mathrm{H} 9 \mathrm{c} 2$ cardiomyocytes. Bioscience Trends, 6: 19-25, 2012.

Han X, Ren D, Fan P, Shen T, Lou H. Protective effects of naringenin-7-0-glucoside on doxorubicin-induced apoptosis in $\mathrm{H} 9 \mathrm{C} 2$ cells. European Journal of Pharmacology, 581: 47-53, 2008.

Itoh K, Masuda M, Naruto S, Murata K, Matsuda H. Effects of unripe Citrus hassaku fruits extract and its flavanone glycosides on blood fluidity. Biological \& Pharmaceutical Bulletin, 33: 659-664, 2010.

Jung HA, Jung MJ, Kim JY, Chung HY, Choi JS. Inhibitory activity of flavonoids from Prunus davidiana and other flavonoids on total ROS and hydroxyl radical generation. Archives of Pharmacal Research, 26: 809-815, 2003.

Kusukawa J, Harada H, Shima I, Sasaguri Y, Kameyama T, Morimatsu M. The significance of epithelial growth factor receptor and matrix metalloproteinase-3 in squamous cell carcinoma of oral cavity. European Journal of Cancer Part B: Oral Oncology, 32B: 217-221, 1996.

Lee YR, Noh EM, Han JH, Kim JM, Hwang JK, Hwang BM, Chung EY, Kim BS, Lee SH, Lee SJ, et al. Brazilin inhibits UVB-induced MMP-1/3 expressions and secretions by suppressing the NF-kB pathway in human dermal fibroblasts. European Journal of Pharmacology, 674: 8086, 2012.

Mays PK, Bishop JE, Laurent GJ. Age-related changes in the proportion of type I and III collagen. Mechanisms of Ageing and Development, 45: 203-212, 1988.

$\mathrm{Na}$ EJ, Yang HO, Choi YE, Han HS, Rhie SJ, Ryu JY. Antiinflammatory and collagen production effect of syringic acid on human keratinocyte (HaCaT) damaged by ultraviolet B. Asian Journal of Beauty and Cosmetology, 16: 523-531, 2018.

Perlish JS, Lemlich G, Fleischmajer R. Identification of collagen fibrils in scleroderma skin. The Journal of Investigative Dermatology, 90: 48-54, 1998.

Rittié L, Fisher GJ. UV-light-induced signal cascades and skin aging. Ageing Research Reviews, 1: 705-720, 2002.

Roshchin YV, Gerashchenko Gl. Anti-inflammatory activity of some flavonoids. Vopr Farm Dal'nem Vostoke, 1: 135, 
1973.

Saito Y, Shiga A, Yoshida Y, Furuhashi T, Fujita Y, Niki E. Effects of a novel gaseous antioxidative system containing a rosemary extract on the oxidation induced by nitrogen dioxide and ultraviolet radiation. Bioscience, Biotechnology, and Biochemisty, 68: 781-786, 2004.

Varani J, Perone P, Fligiel SE, Fisher GJ, Voorhees JJ. Inhibition of type I procollagen production in photodamage: correlation between presence of high molecular weight collagen fragments and reduced procollagen synthesis. Journal of Investigative
Dermatology, 119: 122-129, 2002.

Wlaschek M, Tantcheva-poór I, Naderi L, Ma W, Schneider LA, Razi-Wolf Z, Schüller J, Scharffetter-Kochanek K. Solar UV irradiation and dermal photoaging. Journal of Photochemistry and Photobiology B, 63: 41-51, 2001.

Yoon Y. Gene expression profiling in protection mechanism of silibinin against damage to human dermal fibroblasts caused by UVB. Asian Journal of Beauty and Cosmetology, 11: 93-102, 2013. 


\section{국문초록}

\section{Prunin의 자외선 B에 의해 손상된 인간 각질형성세포 (HaCaT)에 대한 광노화 억제 효과}

류지영 ${ }^{1}$, 이승자 ${ }^{1}$, 임계화 ${ }^{2}$, 최영은 ${ }^{3}$ 한효선 ${ }^{4}$, 양현옥 ${ }^{5}$, 나은주 ${ }^{*}$

${ }^{1}$ 한라대학교 뷰티케어디자인과, 강원도 원주시, 한국

${ }^{2}$ 상지영서대학교 뷰티케어과, 강원도 원주시, 한국

${ }^{3}$ 명지전문대학교 뷰티매니지먼트과, 서울, 한국

${ }^{4}$ 한국피부과학연구원, 서울, 한국

${ }^{5}$ 원광보건대학교 미용피부테라피과, 전라도 익산시, 한국

목적: 본 연구는 UVB로 인해 손상된 인간 각질형성세포(HaCaT)에 대한 prunin의 광노화에 효과가 있는지를 확인하여 노화에 효 과적인 화장품 소재로서 활용 가능성을 알아보기 위함이다. 방법: Prunin의 UVB에 의한 증가된 $M M P 1 \mathrm{mRNA}$ 발현과 UVB에 의 해 감소된 COL1A1 mRNA의 발현은 quantitative real-time polymerase chain reaction (qRT-PCR)을 통해 확인하였고, luciferase reporter assay를 통해 $M M P 1 \mathrm{mRNA}$ 의 변화가 $\mathrm{AP}-1$ 전사 활성과 관련이 되어 있는지 분석하였다. 또한 ELISA 분석으로 type I procollagen의 생성량 변화를 확인하였다. 결과: Prunin은 UVB에 의한 세포독성으로부터 세포를 보호하고, UVB로 손상된 인간 각질형성세포 $(\mathrm{HaCaT})$ 에서 산화 스트레스에 의해 증가된 $M M P 1 \mathrm{mRNA}$ 의 발현이 농도의존적으로 감소하였다. $\mathrm{AP}-1$ 전사활성 또한 농도의존적으로 감소하였다. Type I procollagen과 COL1A1 mRNA 발현이 농도의존적 증가하였다. 결론: 본 연구를 통하여 prunin이 산화 스트레스의 대표가 되는 자외선에 인한 노화 억제 효능이 확인되었으며 이는 광노화에 효과적인 화장품 원료로서 활 용이 가능할 것으로 판단된다. 하지만 현실적으로 화장품 원료로 피부에 사용하기 위해서는 추후 인체를 대상으로 한 실험이 필요 할 것이라 사료된다.

핵심어: Prunin, 광노화, 인간 각질형성세포, $M M P 1$, 자외선 B

참고문헌

나은주, 양현옥, 최영은, 한효선, 이승자, 류지영. 자외선 B에 의해 손상된 인간 각질형성세포(HaCaT)에 대한 Syringic Acid의 염증 억제 및 콜라겐 생성 효과. 아시안뷰티화장품학술지, 16: 523-531, 2018.

윤영민. UVB에 대한 Silibinin의 세포보호 기전에 작용하는 유전자 발현 프로파일링. 아시안뷰티화장품학술지, 11: 93102, 2013. 


\section{中文摘要}

\section{Prunin对UVB辐射损伤人角质形成细胞 (HaCaT) 光老化的抑制作用}

柳枝榮 ${ }^{1}$, 李勝子 ${ }^{1}$, 任桂華 $^{2},{\text { 崔榮殷 }{ }^{3}, \text { 韓孝仙 }^{4}, \text { 梁賢玉 }^{5}, \text { 羅恩朱 }}^{5^{*}}$

汉拏大学美容设计学科, 江原道原州市, 韩国

2尚志嶺西大学美容护理科, 江原道原州市, 韩国

明知大学, 美容管理学科, 首尔, 韩国

韩国皮肤科学研究院，首尔，韩国

5圆光保健大学美容皮肤治疗科，全罗道湓山市，韩国

目的: 探索prunin对UVB辐射损伤的角质形成细胞（HaCaT）光老化的影响，以确定Prunin是否可以作为化妆 品中有效的抗衰老成分。方法: 采用定量实时聚合酶链反应（qRT-PCR）鉴定UVB对MMP1 mRNA表达增加和 COL1A1 mRNA表达降低的影响, 荧光素酶报告基因检测法检测MMP1 mRNA的变化是否相关到AP-1的转录活 性。此外, ELISA分析用于确定I型原胶原产生的变化。结果: Prunin保护细胞免受UVB诱导的细胞毒作用, 并且 UVB损伤的HaCaT中由于氧化应激引起的MMP1 mRNA表达的增加以浓度依赖性方式降低。AP-1转录活性也以 浓度依赖性方式降低。I型原胶原和COL1A1 mRNA的表达以浓度依赖性方式增加。结论: 本研究发现, prunin 对光老化具有抑制作用, 紫外线辐射是氧化应激的主要原因。因此, prunin可用作抑制光老化的有效化妆品原 料。然而，有必要对人体进行实验以找到应用prunin作为皮肤的化妆原料的实用方法。

关键词: Prunin, 光老化, 人角质形成细胞, $M M P 1$, 紫外线B 
